\title{
Pohádkový Honza. Zamyšlení nad jedním z mentalitních symbolů české vesnice druhé poloviny 19. a prvních decennií 20. století
}

\author{
EDUARD KUB U * - JI ǏÍ ŠOUŠA * *
}

\author{
The Storybook Honza. Reflections on One of the Mental Symbols of the Czech Village \\ in the Second Half of the 19th and the First Decades of the 20th Century
}

\begin{abstract}
Knowledge of the fairy tales about Honza has been virtually universal in Czech society since the second half of the 19th century. Czech Honza belongs in the country that represents a whole other world with its own customs and traditions, different from the town, a marginalised world lagging behind the urban world, which is more often than not more refined, perceived in the country as more comfortable and easier to live in. The tales of Honza are tales of emancipation attuned in many respects to the core of the ideology of the agrarian movement of the late nineteenth and the beginning of the twentieth century as an emancipating ideology directed in the Czech milieu at the middle and lower-middle classes, that is farmers and peasants (the countryside being regarded as one big family). Honza is an archetype of the countryman, part of a collective identity whose symbolism acquires in the 20th century a dimension reflecting society, as a whole.
\end{abstract}

Keywords: Czech Honza; archetype of the countryman; tales of emacipation; collective identity

DOI: $10.14712 / 23363525.2017 .27$

Robert Darnton ve své fascinující knize s až rabiátským názvem Velký masakr koček zkoumá francouzské pohádky 17. a 18. století a na jejich základě dospívá k závěru, že jsou výrazem orální tradice vyjadřující určitý sdílený pohled na svět, kulturní vzorec existující na celonárodní úrovni, třebaže $s$ regionálními variantami. ${ }^{1}$ Jeho přístup z hlediska kulturních dějin stavící na metodologii sociální antropologie je velmi nový. Ukazuje, že i pohádka se může stát exkluzivním, jedinečným pramenem historickým, etnologickým či jiným a nemusí být výlučnou doménou literární vědy. Ostatně v uváděném pojednání literárněvědné aspekty nehrají zásadní roli, soustředíme se na aspekt sociálně historický. Darnton na pohádkovém podkladě prezentuje dějiny mentalit, interpretuje duševní obzory prostých lidí ve Francii dané doby. V pohádkách spatřuje symboly a rituály jako širře platné vzorce jednání.

Obdobným směrem se ubírá i naše úvaha o širší symbolice souboru pohádek, jejichž hlavním protagonistou je hloupý, vychytralý, ale někdy také chytrý Honza. Tyto pohádky měly v českém prostředí bohaté zastoupení a námětově tvoří relativně ucelený, neobyčejně

\footnotetext{
" Prof. PhDr. Eduard Kubů, CSc., Ústav hospodářských a sociálních dějin, Filozofická fakulta Univerzity Karlovy, Celetná 20, 11638 Praha 1. E-mail: Eduard.Kubu@ff.cuni.cz.

** Doc. PhDr. Jiří Šouša, CSc., Katedra pomocných věd historických a archivního studia, Filozofická fakulta Univerzity Karlovy, nám. Jana Palacha 2, 11638 Praha 1. E-mail: Jiri.Sousa@ff.cuni.cz.

1 Darnton, Robert [2013]. Velký masakr koček a dalši epizody z francouzské kulturni historie. Praha: Argo.
} 
obsažný soubor spojený několika typologiemi projektování Honzy jako hocha z lidu. Pohádky o Honzovi najdeme v různých původních sbírkách a různých zpracováních. K nejznámějším náleží textace Boženy Němcové, vzniklé před polovinou 19. století. Honza se objevuje v pohádkových antologiích.

Poslední monotematickou a zjevně nejznámější verzi představuje soubor sedmašedesáti textů s příznačným názvem Český Honza, sestavený významným literárním vědcem a etnografem Jiř́m Horákem, s podtitulem Lidové pohádky. ${ }^{2}$ Jeho dílo ovlivnilo několik generací dětí, první čtenáři se s ním mohli seznámit v roce 1940. Doposud vyšlo v celkem sedmnácti nezměněných vydáních, poslední v roce 2013. Enormní popularitě přispěly i skvostné, oku lahodící ilustrace národního umělce Josefa Lady, jež byly snadno srozumitelné a konvenovaly lidovému naturelu. ${ }^{3}$ Titul Český Honza a podtitul Lidové pohádky jako by říkaly, že pohádky o českém Honzovi vznikly v Čechách, jsou produktem domácí lidové tvořivosti. Tak tomu ovšem úplně není.

Žánr lidové pohádky představuje ustálený korpus s danými charakteristikami, který se vyvíjel dlouhá staletí, možná i tisíciletí. Má množství kořenů, jež vzájemně prorůstají, at již se jedná o texty kronik, pověsti, nejrůznější ústní tradici. Odborník si je vědom, že v evropském prostoru a také samozřejmě v prostoru střední Evropy se jedná o jistý př́iběhový základ, který se pak rozvíjí v jednotlivých prostředích s mírnými variacemi. ${ }^{4} \mathrm{~A}$ tak pohádky o Červené karkulce, Šípkové Růžence, Jeníčkovi a Mařence, kocourovi v botách a jiné najdeme $\mathrm{v}$ různých variacích $\mathrm{v}$ prostředí francouzském, stejně jako německém či českém. Nejinak je tomu i s Honzou. Z tohoto hlediska poučnou analýzu Honzy jako protagonisty evropské lidové pohádky v komparaci textů rozličných - třebaže kulturně dílem prolínajících - prostředí stř̌ední Evropy přináší pozoruhodná disertační práce Anny Veliké. ${ }^{5}$

Veliká zdůrazňuje, že daný námět svou podstatou „mezinárodni“ odráží ve svém národním a jazykovém koloritu stereotypní představy vlastního etnika, připomíná, že v českém prostředí se jedná o Honzu hloupého, nebo jen zdánlivě hloupého, na Slovensku o udatného, nebojácného Janka, v německém prostředí antihrdinu grimmovského typu „Hans im Glück“, tj. hlupáka, ve své hlouposti však štastného. ${ }^{6}$ Anna Veliká dokonce zpracovala katalog pohádek o Honzovi, rozdělených do čtyř hlavních kategorií. Rozlišuje mezi „hloupým Honzou“,7 at již „opravdu hloupým“, či „zdánlivě hloupým“, „Honzou chytrým, resp. statečným“, „malým Jankem/Hansem“ a „Honzou ve vedlejší roli“. Kategorie třetí

2 Jiří Horák (1884-1975), slavista, profesor komparatistiky a dějin slovanských literatur na univerzitách v Brně a Praze, etnograf (v letech 1957-1964 byl ředitelem Ústavu pro etnografii a folkloristiku ČSAV) a také diplomat (1945-1947 působil jako velvyslanec v SSSR).

3 Český Honza: Lidové pohádky [1957]. Vybral a upravil Horák, Jiř́í; ilustroval Lada, Josef. 5. vydání, Praha: Albatros.

4 U některých pohádek se zjevně jedná o námětové transfery překračující hranice specificky kulturně vyhraněných prostředí, nicméně na britských ostrovech vznikla i teorie jiná, u jejíhož zrodu stáli Edward Burnett Tylor a Andrew Lang, nazývaná teorií antropologickou. Podle ní nejstarší náboženské principy - vztah těla a duše - byly u všech národů stejné bez výslovného vlivu jednoho národa na druhý, a tak si jsou způsoby myšlení, náboženství a fantazie podobné. Jednotlivé národy tak produkují i podobné pohádky bez závislosti na cizích vzorech.

5 Veliká, Anna [2011]. Hrdina evropské lidové pohádky. Analýza textů z českých zemí, Slovenska, Německa a Rakouska s hlavní postavou Jan/Honza/Hans. Disertační práce. Brno: FF MU.

6 V českém prostředí je variací pohádky bratří Grimmů Hans im Glück pohádka Jak stařeček měnil, až vyměnil, přičemž klasické je zpracování tohoto motivu Františkem Bartošem.

7 Symptomaticky srv. Hloupý Honza: české pohádky [1881]. Vypravuje Quis, Ladislav. Praha: Jos. Er. Vilímek. Další dvě vydání [1892 a 1925], s ilustracemi Mikoláše Alše. Praha: F. Topič. 
a čtvrtá představují kategorie neprofilující, jen minoritně zastoupené. Klíčovými kategoriemi jsou v každém prrípadě „Honza hloupý“ a „Honza statečný“.

Katalog pohádek o Honzovi sestavený Annou Velikou je katalogem současným, v jeho obsahu se objevují lidové pohádky nejrůznějších historických období (zachycených v rozličných historických dobách) s pohádkami autorskými, umělými, jež vyšly z dílen konkrétních autorů. Hybridem mezi nimi jsou pak pohádkové texty, které jsou literárními adaptacemi starých pověstí, pohádek, jejichž zdrojem je lidová tradice, tedy podání vypravěčů. ${ }^{8}$ K tomu je třeba dodat, že charakter pohádek z rozličných zdrojů je velmi nestejný (at již se to týká jazyka, dějové variability a vyústění př́iběhu). Liší se i vedlejší aktéři a prostředky sdělení.

Ve starší vrstvě pohádek je silněji zastoupena pohádka kouzelná, využívající nadpřirozených sil, v novější vrstvě je posílena pohádka tendující spíše k realitě, zhusta se sociálním vyzněním (osobní a sociální spravedlnost). Dokladem toho je soupis pohádek zaměřený na českou lidovou pohádku, provedený v průběhu dvacátých let 20. století významným literárním vědcem Václavem Tillem, publikujícím pod pseudonymem Václav Ríha. ${ }^{9}$ Tille současně náležel k těm, kteří lidové zdroje cestou literární adaptace zpřístupňovali širší veřejnosti. ${ }^{10}$ Jeho soupis je řazen tematicky. Anotace pohádek o hloupém Honzovi pokrývají problematiku k počátku 20. století. Přitom se Tille soustředil na soupis pohádek nikoliv sice primárně autorských, ale z lidových zdrojů či se k nim alespoň hlásících, tj. pohádek, u nichž se nedá s odstupem času stanovit původní zdroj a nelze vyloučit jisté zásahy sběratele či sestavitele pohádkového souboru. Soupis je tematickým zpracováním řady starších edic a souborů. Znamená to, že heslo „hloupý Honza“ obráží nejstarší dochované vrstvy pohádek o „hloupém Honzovi“, ale současně nevylučuje zásahy sběratelů.

Zásadní poznatek shrnující „honzovské“ heslo v Tilleho soupisu říká, že starší verze pohádek jsou výrazně odlišné od pohádek autorsky literárně adaptovaných v období první Československé republiky a později. Soubor dokazuje těsnou námětovou souvislost všech pohádek s klíčovým rozdílem spočívajícím v tom, že jejich vyústění, ač poučné, z valné části nekončí happy endem, ale osudovým dramatem, kde typickou pointou je smrt rodiče zaviněná hloupým a neomaleným potomkem, či dokonce Honzova smrt. Lze v nich najít

8 Šmahelová, Hana [1989]. Návraty a proměny. Literární adaptace lidových pohádek. Praha: Albatros: 133n.

9 Tille, Václav [1929-1937]. Soupis českých pohádek. 3 svazky, Praha: Česká akademie věd a umění. Z Tillem uváděných zdrojů viz Velký národní kalendár pro čas a věčnost na obyčejný rok [1882-1920], Vimperk: J. Steinbrener. Kubín, Josef Štefan [1922-1923]. Lidové povídky z českého Podkrkonoší. Podhoři západní. 3 svazky. Vydal a komentářem kriticko-bibliografickým opatřil Polívka, Jiří. Praha: Česká akademie věd a umění. Kubín, Josef Štefan [1926]. Lidové pohádky z českého Podkrkonoší. Úkrají východní. Vydal a komentářem kritickobibliografickým opatřil Polívka, Jiří. Praha: Česká akademie věd a umění. Polívka, Jiří [1929]. Lidové povídky slovanské. Vybrané rozpravy uspořádali Horák, Jiří a Tille, Václav. Praha: Národopisná společnost československá. Biliánová, Popelka [1922]. Po cestičkách k oltáři [povídky]. Ilustroval Rélink, Karel. Praha: A. Neubert. Sedláček, Hanuš [1929]. Štastný rok: pohádky, povídky, verše a písně pro nejmladší čtenáře. Ilustroval Vrobek, Fr. Praha: Volná myšlenka. Soukal, Josef [1889]. Z našich luhư: básně a povídky. Praha: Alois Hynek. Sebrané spisy Františky Stránecké [1889-1893]. 1. díl, Povídky, obrazy a črty. Svazek 1-3, Velké Meziříčí: J. F. Šašek.

10 Václav Tille (1867-1937), divadelní a literární kritik, univerzitní pedagog, prozaik, knihovník. Po absolvování slavistiky a germanistiky na univerzitách v Praze a Innsbrucku pracoval v pražské univerzitní knihovně, olomoucké studijní knihovně a v knihovně Národního muzea. V roce 1903 se habilitoval; v letech 1921-1937 byl profesorem srovnávacích dějin na Karlově univerzitě. Uveřejnil řadu divadelních a literárních kritik v denním tisku a mnoho komparativních studií o umění scénickém a mimickém, kriticky analyzoval povídkovou a pohádkovou tvorbu a zabýval se dalšími obory české i zahraniční literatury a knihovnictví. Pod pseudonymem Václav Ríha psal pohádky pro děti. Angažoval se také v intelektuálním světě - byl členem Rotary klubu, Evropského literárního klubu a spoluzakladatelem českého PEN klubu. 
i další zápletky dnes obecně nazírané jako surové. Honza potmě sní pět živých kotat či Honza vylupuje živým tvorům - kozám, ovcím, králíkům, slepicím - oči, které hází po potenciálních nevěstách (výzva, aby se Honza poohlédl - hodil okem - po nevěstě je dovedena do absurdního vyznění). Často pohádka končí neutrálně ve smyslu „hlupák jednou pro vždy zůstane hlupákem“. Někdy jakoby konstatuje, že člověk má zůstat tam, kde patří, Honza se vrací, odkud přišel, v některých verzích odmítá nabídnuté bohatství v duchu úsloví „všude dobře, doma nejlíp“. Jen menší část pohádek končí pozitivně - zmoudřením Honzy, jeho zbohatnutím a štastnou ženitbou. Tilleho námětový soubor akcentující didakticky odstrašující vyústění příběhu nápadně připomíná starší typy pohádek hraničící se syrovým naturalismem, na nějž upozorňuje ve své práci o korpusu francouzských pohádek 17. a 18. století Robert Darnton. Jejich až hororová strašidelnost připomíná atmosféru pohádek bratří Grimmů11 či Hanse Christiana Andersena.

Boženou Němcovou ovšem začíná v českém prostředí nová etapa ve vývoji námětů „honzovských“ pohádek, mění se totiž Honzův charakter a především celkové vyznění příběhu. Pohádky se blíží modernímu tvaru běžnému ve 20. století, který pracuje s osvědčenými výchovnými stereotypy, nabádá k píli, pracovitosti, solidární dobrosrdečnosti, s ponaučením, že dobro bývá honorováno dobrem, což vše rezultuje v optimistickém vyústění děje. Pohádka se stala čtivou, zábavnou a radostnou zároveň. Dosavadní často velmi syrový obsah spojený i s erotickým nábojem v lidovém podání pohádek ochotně korigovali a upravovali sami sběratelé. ${ }^{12}$ Ani Němcová nereprodukovala české pohádky dokumentaristickou formou, při jejich zachycování využívala svého neobyčejného vypravěčského talentu. Pohádky Němcové se staly klasickými díly, jež určovala další vývoj. Jejím přínosem je i veselá pohádka žertovného charakteru. Prototypem veselé dobrosrdečné pohádky jsou (počínaje Němcovou, ale především po Němcové) pohádky o Honzovi, jejichž množství narůstá. Do pohádkového „honzovského“ diskurzu vstupuje celá řada autorů, ve 20. století i zavedených a počítaných mezi klasiky, z oněch starších připomeňme alespoň Beneše Methoda Kuldu s moravskými národními pohádkami ${ }^{13}$ či Václava Ríhu (pseudonym již zmíněného Václava Tilleho) ${ }^{14}$, jenž se významně zasloužil o ustálení Honzova pozitivního obrazu. ${ }^{15}$

Z mladších publikací pohádek o Honzovi vyšlých po 1. světové válce uved’me Dárek od pohádky Josefa Štefana Kubína ${ }^{16}$ či pohádky Jindřicha Šimona Baara situované na Chodsko a využívající místní nářečí. ${ }^{17}$ Poměrně pozdě, v padesátých letech, vydal svého neobyčejně populárního Českého Honzu Jan Drda, jemuž Honza posloužil jako protagonista

11 Bratři Grimmové chápali lid jako nositele lidové slovesnosti, avšak ani u nich nebylo doslovné přepsání pohádky z ústní tradice zřejmě pravidlem. Do svých sbírek nezahrnovali pohádky, které neodpovídaly jejich představám o „čistotě textu a pojednání“. Grimmovská pohádka se stala novou normou ovlivňující vývoj žánru ve stř̀ední Evropè.

12 [Veliká 2011: 49].

13 Kulda, Beneš Method [1874 + řada dalších vydání]. Moravské národní pohádky. Praha: I. L. Kober.

14 Ŕíha, Václav [1904]. Alšovy pohádky. Praha: Dědictví Komenského. Dále např. Ř́ha, Václav [1987]. Knížka pohádek. Praha: Albatros.

15 Z jedenácti textů Alšových pohádek vydaných roku 1950 je jich hned šest věnováno Honzovi, všechny bez výjimky mají pozitivní vyústění.

16 Kubín, Josef Štefan [1924 nebo 1925]. Dárek od pohádky. Praha: Českomoravské podniky tiskařské a vydavatelské.

17 Baar, Jindřich Šimon [1922]. Chodské povídky a pohádky. Praha: Československé podniky tiskařské a vydavatelské. 
i v dalších oblíbených pohádkách (nap̌r. Jak šel Honza do Lenoráje). Drda více či méně čerpal z lidového rezervoáru a vytvářel nový obraz českého Honzy. Honzovské př́iběhy doby romantismu se postupně přetvářely v př́iběhy aktuálně časové, promlouvající $k$ době meziválečné i poválečné. Drdův Český Honza je mimo jiné podobenstvím boje proti cizímu nepř́teli (s německým jménem), reprezentovanému králem, autoritativním, sobeckým a záludným, jenž uzavřel spojenectví s drakem proti svým poddaným, a proto spravedlivě končí „jako haraburdí, které již nikdo nepotřebuje“. ${ }^{18}$ Inovovaná pohádka, čítající desítky stran, je zjevně určena i zábavě starších čtenářủ, nejen malých dětí. Do textu již vstupují emoce a tělesnost (pohlazení; políbení, z něhož se mu hlava zatočila; Honza smrdí koňským hnojem). Širokou oblibu této pohádky umocnilo její zfilmování.

Karel Čapek v Lidových novinách v roce 1931 napsal:

Hloupý Honza je téměř univerzální pohádkový typus. Jsou př́ípady, kdy to není ani hrdina, ani chytrák, nýbrž obyčejný prostý a dobrosrdečný nádiva, který je pro smích všem a nehodí se k ničemu, ale jemuž vyšší spravedlnost a lahodná demokratičnost pohádek nadělí korunu královskou a veškeré dary života. Úspěchu je možno dobývat silnými činy, je možno jej vytaškařit vlastní chytrostí; ale což i my nečekáme, že nám snad štěstí spadne do klína jako milost, že k němu přijdeme jako slepí $\mathrm{k}$ houslím, že to pravé štěstí není zásluha, nýbrž úsměvný a tajemně štědrý dar? Potká-li nás něco dobrého, přijímáme to ne jako zaslouženou odměnu, ale trochu zmateni, drobet nejistí, zda se nám to jenom nezdá; každý z nás ve zvláště štastném okamžiku byl hloupým Honzou, který k štěstí přišel. ${ }^{19}$

Z hlediska obrazu českého Honzy v české společnosti, jak se ustálil v období meziválečném a jak jej téměř petrifikoval již zmíněný zdařilý výbor Horákủv, není v zásadě podstatné, zda se jedná o obraz spočívající pevně na základech lidové slovesnosti, či obraz modifikovaný, přepracovaný a uzpůsobený estetickým dobovým standardům a situaci české společnosti autorsky, či zda se dokonce jedná o pohádky ryze autorské. Podstatný je obraz v širokém kulturním povědomí a je tř̌eba říci, že i to v pohádkách nepůvodní, co bylo do př́iběhu uměle vloženo, nakonec tím, že se stalo součástí výsledného honzovského korpusu, zlidovělo a je za lidové považováno. Zkrátka v našem zkoumání nejde o samotný bezprostřední původ a vznik pohádky, nýbrž o její reflexi a rozšiřrení mezi recipienty, její aktualizovaný sociální kontext. $V$ každém př́padě pohádky pracujís reáliemi venkovského života, se stereotypy uvažování venkovského lidu, jeho obzory a dílem i problémy, a to se značným zpožděním, které obráží mentální struktury a stereotypy prostředí celá dlouhá desetiletí do minulosti. $\mathrm{V}$ procesu změny vykazují jejich staré podoby poměrně dlouhý poločas rozpadu. I pohádka o Honzovi je stejně jako další pohádky jednou ze symptomatických výpovědí o charakteru českého venkova druhé poloviny 19. a prvních desetiletí 20. století. Zkrátka k pohádce je možné také přistupovat jako ke svébytnému literárnímu pramenu symbolizujícímu obraz a problémy určité doby. ${ }^{20}$ Ostatně lidové pohádce se na počátku 20. století dostalo pozornosti nejen literárních vědců, ale i třeba národopisců, do hry vstupují také psychologie a pedagogika. V padesátých letech 20. století švýcarský

${ }_{18}$ Drda, Jan [1990]. České pohádky. Praha: Albatros: 114.

19 Čapek, Karel [1971]. Marsyas čili na okraj literatury (1919-1931). Praha: Československý spisovatel: 122.

${ }^{20} \mathrm{~K}$ literatuře jako historickému pramenu srv. Kubů, Eduard - Šouša, Jiř́ - Zářický, Aleš (ed.) [2014]. Český a německý sedlák v zrcadle krásné literatury 1848-1948. Diskurz mezi historií a literární vědou na téma selského a hraničárského románu. Praha: Dokořán (srv. zejména úvod). 
badatel Max Lüthi vnesl do zkoumání pohádek i pohled vycházející z děl Sigmunda Freuda a Carla Gustava Junga, najdeme ho i u již zmiňovaného Roberta Darntona. Psychologický směr pohádkoslovného bádání akcentuje $\mathrm{v}$ pohádce reflexi vývoje člověka, především jeho integrační proces, tj. začleňování jednotlivce-dítěte do společnosti. ${ }^{21}$

Sepětí českého Honzy se světem venkova nepotřebuje ovšem žádná hluboká či složitá vysvětlení, sotva mohou být venkovštější pohádky, než jsou pohádky o Honzovi. Honza klasicky pochází z venkovského statku či chalupy, nezřídka mluví nářečím. Často dokonce vyrůstá v nuzných poměrech, rodiče ho neuživí, a proto se vydává do světa.

Reálie, které se v pohádkách promítají, náleží k venkovské každodennosti. V Českém Honzovi je jich dokonce takové množství, že Horák ve svém výboru považoval za užitečné a vhodné zpracovat jejich výkladový slovníček, nebơ $\mathrm{v}$ méně zauživaných příměrech hovorové češtiny část pojmů ztratila kolem poloviny 20. století pro většinu obyvatelstva, zejména městského, již svůj význam a stala se nesrozumitelnou. Pohádka tak svým způsobem „vracela“ venkov s jeho reáliemi a specifiky do širšího povědomí.

Jak píše Anna Veliká, slyšíme-li v českém prostředí výraz „hloupý Honza“, máme před očima hocha ležícího na peci, který je líný a pořád jen jí, ale který v rozhodujících momentech překoná své negativní vlastnosti, zachrání princeznu, a tak přijde ke svému štěstí. ${ }^{22}$ Honzova postava má tři základní polohy. $\mathrm{V}$ první $\mathrm{z}$ nich je Honza skutečně poněkud "přihlouplý", jeho hloupost spočívá v tom, že věci chápe doslovně. Mentálně nevyvinutý jedináček přechází ze světa domácnosti do venkovního světa, kde se chová nešikovně; bud’ rady uplatňuje doslova, nebo je nadsadí, či dokonce převrátí. Je mu cizí príměrová symbolika vyjadřování. Paradoxně se ovšem ukazuje, že Honzova hloupost se stává př́nosem. Klíčem k tomuto obratu je zpravidla dobré srdce, které mu otevírá cestu k bohatství. Charakteristickým znakem uvedeného typu Honzy je naivita a skutečnost, že jeho základní vlastnost, tj. hloupost, se nemění. Obvykle se nedopracovává vyššího sociálního postavení. Bud’ se znovu vrací za pec, nebo si bere za ženu selskou dívku, jeho sociální status se nezměnil a Honza v něm zůstává štasten.

Druhou polohou „hloupého Honzy“ je Honza jen zdánlivě hloupý a tento typ se v českém prostředí vyskytuje nejčastěji. Tento Honza je líný, mlsný, okolím považovaný za hlupáka, jenž ovšem v rozhodujících okamžicích svým jednáním - ctnostným a poctivým zachrání princeznu a přijde ke svému štěstí. Tento všeobecně podceňovaný Honza svým úspěchem okolí př̌kvapí. Př́běh neposkytuje pro hrdinovu hloupost důkaz. Honza své schopnosti zprvu nedemonstruje, ale v průběhu děje se mění v chytrého či vychytralého. Zatímco opravdu hloupý Honza přichází k penězům díky hlouposti či náhodě, zdánlivě hloupý Honza často využívá pomoci nadpřirozených sil. Objevují se však i rozličná žertovná vyústění.

Třetí významnou polohu reprezentuje Honza chytrý, resp. statečný. Tento Honza se s vyloučením kouzelného světa úspěšně za pomoci zdravého selského rozumu, síly,

\footnotetext{
${ }^{21}$ Lüthi, Max [1960]. Das europäische Volksmärchen. Form und Wesen. 2. vydání, Bern - München: Francke Verlag: 107. Srv. [Veliká 2011: 35] či [Darnton 2013: 29].

22 [Veliká 2011: 112].
} 
potažmo statečného chování potýká s nadpřirozenými bytostmi. Jeho charakteristickými protivníky jsou čerti, duchové a draci. Nečisté síly jsou přelstěny, či dokonce zabity. Honza hloupý a zdánlivě hloupý zpravidla neř́dí svůj život sám, je jím veden, at již kouzelnými bytostmi či náhodou. Honza „Nebojsa“ je naproti tomu v ději klíčovým aktérem.

Pohádka má v první řadě funkci zábavnou a po ní následuje funkce poučná. Nabízí svět srozumitelný oproti nejasné skutečnosti. Zlo v pohádce je vypočitatelné a ohraničené. Moderní pohádka na rozdíl od jiných literárních textů a také pověsti nezprostředkovává hrůzu. Pohádka nabízí svět jistoty, v němž je nakonec vše uspokojivě zvládnuto, nabízí svět, který „je v pořádku“ a má svá pravidla. Vše je takové, jaké má být. Pohádka není stabilní útvar - je formována autory i tradicí, mění se v prostoru i čase, vyvíjí se. Reflektuje vkus doby, někdy zachovává původní reálie, jindy jsou do ní vnášeny reálie nové - ony lidové mívají historizující rámec. Pohádka tak koresponduje s mentálními stereotypy společnosti, jíž je nesena. Realistická pohádka obráží plebejský stř́zlivý svět venkovana. Přestože je označena za „realistickou“, její svět a děj jsou ploché, vytrácí se z nich propracovanost samožrejmých aspektů života, láska, nenávist, tělesnost/sexualita, úmornost dřiny na poli a jiné. Pokud se do ní tyto jevy promítají, nezachycuje jejich složitost a vzájemnou podmíněnost. Na druhou stranu zahrnuje symbolické kódy venkovského života, at již je to jídlo, křest, svatba, pohřeb, práce v hospodářství. Tyto funkce pohádky o českém Honzovi jsou $\mathrm{v}$ zásadě obecně známé a přijaté. Je tu však ještě jedna funkční vrstva, méně nápadná, na niž se fakticky zapomnělo, a to je funkce identitní.

Český Honza patří na venkov, který představuje svět svébytný s vlastními zvyky a obyčeji odlišnými od města, svět marginalizovaný, zaostávající za světem městským, pestřejším, povětšině lesklejším, vnímaným na venkově jako blahobytnější a snazší. A tak pohádky o Honzovi jsou také pohádkami emancipačními, které v mnohém souzní s obsahem ideologie agrarismu ${ }^{23}$ sklonku devatenáctého století a počátku století dvacátého, agrarismu jako ideologie zrovnoprávňující, v českém prostř̌edí zaměřené na střední a nižší střední vrstvu, tedy sedláky a rolníky (srv. klíčové heslo České agrární strany „Venkov jedna rodina“). Honza tedy může být vnímán jako symbol venkovské společnosti, jako někdo, kdo se nezaslouženě nachází v inferiorním postavení a bojuje o své uznání, širre míněno: o společenské uznání svého stavu. Český Honza v sobě skrývá emancipační obsah vývoje českého venkova závěru 19. a počátku 20. století. Honza touží po větší spravedlnosti, $k$ níž často dochází nápravou shora, tj. rozumnou vládou rozumného člověka. Tento aspekt pohádek velmi hezky vyjádřil Václav Říha (Tille) v závěru díla „Honza v zakletém zámku“: „Tak se stal Honza pánem celého kraje, podělil všechny spravedlivě a všem se pod ním dobře

${ }^{23}$ Agrarismus je politická, ale i stavovská ideologie, jež vyšla ze západní Evropy, zejména Francie, a přes Německo zapustila kořeny v českých zemích. Je vnímána i jako součást životního stylu, má řadu regionálních podob odvíjejících se od specifik regionálních ekonomických vývojů a vývojů nacionálních společenství, nezrrídka i jejich konfrontací. Rámcově lze říci, že většina variací agrarismu vychází z principu, že půda je hlavním národním bohatstvím, rozvoj národního hospodářství se musí opírat o sektor zemědělství a osobám v něm pracujícím musí být poskytnuto adekvátní místo ve společnosti vyjádřené náležitým zastoupením v politickém systému (vychází se z teze politické a sociální inferiority zemědělců). Blíže srv. Kubů, Eduard - Lorenz, Torsten - Müller, Uwe - Šouša, Jiř́ (ed.) [2013]. Agrarismus und Agrareliten in Ostmitteleuropa. Berlin - Praha: BWV Berliner Wissenschafts-Verlag - Dokořán. 
dařilo, měli všeho dost, ještě jim vybývalo. Takové př́iběhy si vypravovali za starých časů, kdy vládli páni a bohatli z práce chudých. " ${ }^{24} \mathrm{~S}$ režimem padesátých let symbioticky tvořící Jan Drda ve své zlidovělé pohádce Český Honza, skvělé jeho vypravěčským stylem, podtrhuje sociální vyznění Honzy výsměchem hlouposti a pokryteckému pobožnůstkářství, kritikou proradnosti a zkorumpovanosti lidí bohatých a mocných. ${ }^{25} \mathrm{~V}$ př́ípadě, že bychom chtěli uplatnit na českého Honzu teorii kolektivního nevědomí, formulovanou Carlem Gustavem Jungem, mohli bychom dojít k názoru, že pohádka vyjadřuje také vrstvy selské mysli, která využívá symbolů k uchopení všeobecně platných lidských témat. Český Honza je tak jistým archetypem venkovana, součástí skupinové identity, obrazem společnosti žijící ve stejných kulisách, společnosti směřující k lepšímu tradičnímu světu, světu spravedlivému, charakteristickému srozumitelností, nekomplikovaností řešení. Honza může být ovšem také vykládán jako výraz soudobého vyrovnávání a identifikace s minulostí.

Znalost pohádek o Honzovi je od druhé poloviny 19. století v české společnosti v zásadě univerzální. „Honza“ se po dlouhé generace zdařile reprodukoval v nejrůznějších variacích a postupně se stával ve své chytrosti, vychytralosti, statečnosti či hlouposti symbolem češství. Tvořil nepřehlédnutelnou charakteristickou součást lidové kultury a její hranice jako by překračoval do celospolečenského rozměru. Honza samozřejmě vstoupil i do české idiomatiky. V jazyce závěru 20. století hloupý (český) Honza značí „člověka z lidu“, „typ prostého, dobromyslného, zdánlivě hloupého, ale statného a statečného člověka, zpravidla mladíka“. ${ }^{26}$ Stačí vzpomenout na přirovnání „tváří se jak hloupý Honza“, či „směje se jak hloupý Honza na jelito“.27 Korpus psaných textů syn2015 (Český národní korpus) nabízí u „hloupého Honzy“ dvacet devět symptomatických příkladů použití, u „českého Honzy“ pak patnáct. ${ }^{28}$

Ne náhodou Jiří Horák nazval svůj soubor Český Honza. Chceme-li zkoumat vypovídací potenciál právě této knihy pro národní identitu, musíme vzít v potaz skutečnost, že poprvé vyšla $\mathrm{v}$ době pro český národ neobyčejně těžké a skličující, na počátku nacistické okupace v roce 1940. Pohádka o Honzovi tak nabývá ještě dalšího obsahu, Honza se stává symbolem přežití, vyrovnání se s problémy chytrostí, vychytralostí a odvahou, většinou skrytými za mimikry zdánlivé hlouposti. Pohádka vnášela do dětských duší to, co bylo pro dospělé tak obtižné.

Oblibě pohádkového Honzy ve 20. století přispívá řada divadelních adaptací pohádek, dokonce i loutkových, ale třeba i hudební zpracování Pohádky o Honzovi Oskara Nedbala z roku 1902, jež se staly stabilní součástí repertoárového fundusu českých divadel. V nejmladších generacích oblibu Honzy petrifikovaly rozhlasové, ale zejména filmové a televizní adaptace českého Honzy s předními hereckými osobnostmi, tradičně dobývající svůj prostor ve svátečních dnech roku. Z oněch filmových vzpomeňme díla Honza málem králem režiséra Bořivoje Zemana (1977), O chytrém Honzovi aneb Jak se Honza stal králem (1985) Ludvíka Ráži, Princezna Hyacinta a tříhlavý drak (1990) Miloše Bobka a naposledy neobyčejně populární adaptace Drdova hloupého Honzy ve filmu $Z$ pekla štěstí Zdeňka Trošky z roku 1999.

${ }^{24}$ [Říha 1904: 85]. Nelze ovšem vyloučit, že poslední větu jako dodatek připojil až v padesátých letech vydavatel.

25 [Šmahelová 1989: 164].

26 Slovník české frazeologie a idiomatiky. Výrazy neslovesné [1988]. Praha: Academia: 100.

27 Slovník české frazeologie a idiomatiky. Přirovnání [1983]. Praha: Academia: 117.

${ }^{28}$ Srv. na stránkách ČNK (www.korpus.cz) hesla hloupý Honza; český Honza. 
Druhá polovina 20. století však nabízí i jiné symbolické porozumění postavě českého Honzy, je to truhlík a zmatkař, komická postava náležející k češství. ${ }^{29}$ Honza se stává v dětském světě se pohybujícím př́ibuzným Haškova dobrého vojáka Švejka. Rázně vstupuje i do světa dospělých. Honza má oproti Švejkovi přece jen o něco málo navíc, je nejen vychytralý, ale někdy i chytrý a udatný. Co je jim společné, je neobyčejná schopnost přežití.

\section{Literatura}

Baar, Jindřich Šimon [1922]. Chodské povídky a pohádky. Praha: Československé podniky tiskařské a vydavatelské.

Biliánová, Popelka [1922]. Po cestičkách k oltáři. Ilustroval Rélink, Karel. Praha: A. Neubert.

Čapek, Karel [1971]. Marsyas čili na okraj literatury (1919-1931). Praha: Československý spisovatel.

Český Honza: Lidové pohádky [1957]. Vybral a upravil Jiří Horák, ilustroval Josef Lada. 5. vydání, Praha: Albatros.

Darnton, Robert [2013]. Velký masakr koček a dalši epizody z francouzské kulturní historie. Praha: Argo.

Drda, Jan [1990]. České pohádky. Praha: Albatros.

Hloupý Honza: české pohádky [1881]. Vypravuje Quis, Ladislav. Praha: Jos. Er. Vilímek. Další dvě vydání [1892 a 1925], s ilustracemi Mikoláše Alše. Praha: F. Topič.

Kubín, Josef Štefan [1922-1923]. Lidové povídky z českého Podkrkonoší. Podhoři západní. 3 svazky. Vydal a komentářem kriticko-bibliografickým opatřil Polívka, Jiří. Praha: Česká akademie věd a umění.

Kubín, Josef Štefan [1924 nebo 1925]. Dárek od pohádky. Praha: Českomoravské podniky tiskařské a vydavatelské.

Kubín, Josef Štefan [1926]. Lidové pohádky z českého Podkrkonoší. Úkrají východní. Vydal a komentářem kriticko-bibliografickým opatřil Polívka, Jiří. Praha: Česká akademie věd a umění.

Kubů, Eduard - Lorenz, Torsten - Müller, Uwe - Šouša, Jiří (ed.) [2013]. Agrarismus und Agrareliten in Ostmitteleuropa. Berlin - Praha: BWV Berliner Wissenschafts-Verlag - Dokořán.

Kubů, Eduard - Šouša, Jiří - Zářický, Aleš (ed.) [2014]. Český a německý sedlák v zrcadle krásné literatury 1848-1948. Diskurz mezi historií a literární vědou na téma selského a hraničářského románu. Praha: Dokořán.

Kulda, Beneš Method [1874 + řada dalších vydání]. Moravské národní pohádky. Praha: I. L. Kober.

Lüthi, Max [1960]. Das europäische Volksmärchen. Form und Wesen. 2. vydání, Bern - München: Francke Verlag.

Polívka, Jiří [1929]. Lidové povídky slovanské. Vybrané rozpravy uspořádali Horák, Jiří a Tille, Václav. Praha: Národopisná společnost československá.

Ř́ha, Václav [1904]. Alšovy pohádky. Praha: Dědictví Komenského. Dále např. Říha, Václav [1987]. Knížka pohádek. Praha: Albatros.

Sebrané spisy Františky Stránecké [1889-1893]. 1. díl, Povídky, obrazy a črty. Svazek 1-3, Velké Meziříćí: J. F. Šašek.

Sedláček, Hanuš [1929]. Štastný rok: pohádky, povídky, verše a pisně pro nejmladší čtenáře. Ilustroval Vrobek, Fr. Praha: Volná myšlenka.

Slovník české frazeologie a idiomatiky. Výrazy neslovesné [1988]. Praha: Academia.

Slovník české frazeologie a idiomatiky. Přirovnání [1983]. Praha: Academia.

Soukal, Josef [1889]. Z našich luhů: básně a povídky. Praha: Alois Hynek.

Šmahelová, Hana [1989]. Návraty a proměny. Literární adaptace lidových pohádek. Praha: Albatros.

Tille, Václav [1929-1937]. Soupis českých pohádek. 3 svazky, Praha: Česká akademie věd a umění

Veliká, Anna [2011]. Hrdina evropské lidové pohádky. Analýza textů z českých zemí, Slovenska, Německa a Rakouska s hlavní postavou Jan/Honza/Hans. Brno: Disertační práce FF MU.

Velký národní kalendár pro čas a věčnost na obyčejný rok [1882-1920]. Vimperk: J. Steinbrener.

29 Na hře se symbolikou českého Honzy postavil např́klad svou esej věnovanou české politické scéně na stránkách nejstaršího domácího internetového deníku Neviditelný pes Luděk Frýbort. Frýbort, Luděk [11. 4. 2014]. Česká anomálie aneb Udatný princ a hloupý Honza. Neviditelný pes. 
Eduard Kubů (*1951) působí paralelně na Ústavu hospodářských a sociálních dèjin Filozofické fakulty Univerzity Karlovy, na Katedře mikroekonomie Podnikohospodářské fakulty Vysoké školy ekonomické a na Katedře ekonomie na UNICORN COLLEGE. Spektrum jeho zájmu zahrnuje moderní politické, hospodářské a sociální dějiny střední Evropy a speciálně pak českých zemí 19. a 20. století. Autor, spoluautor a editor řady monografí a studí týkajících se prvni Československé republiky a zahraniční politiky, československého odboje za první světové války, dějin peněžnictví, ekonomiky holocaustu, hospodářského nacionalismu, agrárních dějin a agrarismu.

Jiř́ Šouša (*1952) přednáší na Katedře pomocných věd historických a archivního studia Filozofické fakulty Univerzity Karlovy. Zaměruje se na hospodářské dějiny 19. a 20. století, moderní pomocné vědy historické, zejména novověkou diplomatiku, numizmatiku, dèjiny správy, ekonomické vztahy českých zemí k Latinské Americe, agrární dějiny a agrarismus. Autor, spoluautor a editor řady monografií a studií. 